\title{
PENGARUH MUTASI PEGAWAI TERHADAP PRESTASI KERJA PADA PEMERINTAH KABUPATEN LAMPUNG TENGAH
}

\author{
Eka Ubaya Taruna Rauf \\ Fakultas Ilmu Sosial dan Ilmu Politik Universitas Sang Bumi Ruwa Jurai \\ ekaubaya77@gmail.com
}

\begin{abstract}
ABSTRAK
Tujuan penelitian ini adalah untuk mendeskripsikan pelaksanaan mutasi pegawai pada Pemerintah Daerah Kabupaten Lampung Tengah, menganalisis prestasi kerja pegawai pada Pemerintah Daerah Kabupaten Lampung Tengah, menganalisis pengaruh mutasi pegawai terhadap prestasi pegawai pada Pemerintah Daerah Kabupaten Lampung Tengah. Hasil analisis regresi diketahui bahwa Pelaksanaan Mutasi Pegawai pada Pemerintah Daerah Kabupaten Lampung Tengah, terdapat pola pengaruh positif dan signifikan antara mutasi Pegawai (X) terhadap prestasi kerja (Y) pada Pemerintah Daerah Kabupaten Lampung Tengah. Bahwa apabila mutasi. Metode penelitian yang digunakan adalah quisioner dan dokumentasi serta analisis data yang digunakan adalah analisis kuantitatif dengan bantuan program SPSS Versi 16.0 for windows untuk memudahkan pengerjaan, dengan menggunakan alat analisis Persamaaan Regresi Linier Sederhana. Keterkaitan pengaruh antara mutasi Pegawai dengan prestasi kerja Pemerintah Daerah Kabupaten Lampung Tengah adalah 0,986 atau 98,6 \% Dengan demikian menunjukan bahwa ada pengaruh yang erat antara mutasi Pegawai dengan prestasi kerja. Besarnya pengaruh variabel bebas mutasi Pegawai (X) terhadap variabel terikat prestasi kerja (Y) sebesar 0,973 atau 97,3\%. Sedangkan sisanya 2,7 \% dipengaruhi atau dijelaskan oleh variabel lain yang tidak dimasukkan ke dalam metode penelian ini.
\end{abstract}

Kata kunci : mutasi pegawai, prestasi kerja, pemerintah

\begin{abstract}
The purpose of this study was to describe the implementation of employee mutations in the Central Lampung District Government, analyze employee work performance in the Central Lampung District Government, analyze the effect of employee mutations on employee performance in the Central Lampung District Government. The results of the regression analysis note that the Implementation of Employee Movements in the Central Lampung District Government, there is a pattern of positive and significant influence between Employee mutations $(X)$ on work performance $(Y)$ in the Central Lampung District Government. The research method used was questionnaire and documentation as well as data analysis used was quantitative analysis with the help of the SPSS Version 16.0 for windows program to facilitate workmanship, using the Simple Linear Regression Equation analysis tool. The correlation between employee mutations and work performance of Central Lampung Regency is 0.986 or 98.6\%. Thus, it shows that there is a close influence between employee mutations and work performance. The magnitude of the influence of the Employee mutation free variable $(X)$ on the work performance dependent variable $(Y)$ was 0.973 or $97.3 \%$. While the remaining $2.7 \%$ is influenced or explained by other variables not included in this research method.
\end{abstract}

Keywords: employee movements, job performance, goverment 
PENDAHULUAN

Pembangunan pada hakekatnya adalah kesadaran atau keinsyafan untuk melakukan kegiatan memperbaiki, mendirikan bahkan menumbuhkan serta meningkatkan daya upaya yang mengarah kepada keadaan yang lebih baik dengan dilandasi oleh prestasi, kemauan dan tekad yang tinggi yang bertujuan untuk melakukan kegiatankegiatan yang bersifat memperbaiki dan meningkatkan kesejahteraan rakyat Indonesia pada umumnya. Menurut Nitisemito, (2016:44)

Tujuan tersebut baru dapat dicapai apabila pembangunan nasional dilaksanakan secara menyeluruh dengan pemanfaatan sumber daya manusia dan sumber daya bukan manusia, serta pelaksanaan pembangunan disegala bidang, terencana, terarah, bertahap dan berkesinambungan. Salah satu bidang tersebut adalah pembangunan manusia seutuhnya. Dalam hal ini keberhasilan pembangunan tergantung pada aspek manusianya yakni sebagai pemimpin, pelaksana dan pengelola sumber daya yang ada dalam nagara, yang dalam hal ini adalah Pegawai Negeri Sipil (PNS), terutama pada Pemerintah Daerah Kabupaten Lampung Tengah.
Pemerintah Daerah Kabupaten Lampung Tengah menganggap bahwa sumber daya manusia dalam hal ini pegawai merupakan aset yang sangat menentukan kinerja perusahaan. Oleh karena itu, salah satu alternatif yang dilakukan oleh Pemerintah Daerah Kabupaten Lampung Tengah adalah dengan cara "program mutasi Pegawai". Hal ini sengaja dilakukannya, agar atmospher dan lingkungan kerja pada unit-unit kerja ada perubahan. Selain daripada itu, juga adanya keinginan dari manajemen sumber daya manusia (manajemen Pegawaiia) untuk memotivasi para pegawai agar dapat meraih prestasi kerja yang lebih baik.

Dengan demikian, para pegawai akan dapat memperoleh kesempatan terhadap suatu perubahan, baik melaluiprogram mutasi jabatan atau pun program promosi jabatan dari perusahaan dalam hal ini Badan Kepegawaian Daerah Kabupaten Lampung Tengah. Progam promosi Pegawai dan program mutasi Pegawai merupakan alternatif penting bagi Badan Kepegawaian Daerah Kabupaten Lampung Tengah dalam upaya untuk menyelenggarakan dan menggunakan serta memanfaatkan sumber daya 
manusia yang ada dalam perusahaan agar dapat berjalan sesuai dengan fungsinya masing-masing.

Berdasarkan literatur yang ada, mutasi Pegawai itu sendiri merupakan salah satu cara untuk memberdayakan pegawai agar dapat meningkatkan kinerja dalam upaya menyelaraskan dengan tujuan organisasi. Oleh karena itulah sumber daya manusia yang tersedia harus senantiasa dibina, dilatih, dan dikembangkan sesuai dengan tugas pokok di bidangnya masing-masing. Menurut Nitisemito, (2016:132) Mutasi adalah kegiatan memindahkan tenaga kerja dari satu tempat tenaga kerja ke tempat kerja lain. Akan tetapi mutasi tidak selamanya sama dengan pemindahan. Mutasi meliputi kegiatan memindahkan tenaga kerja, pengoperan tanggung jawab, pemindahan status ketenagakerjaan, dan sejenisnya. Adapun pemindahan hanya terbatas pada mengalihkan tenaga kerja dari satu tempat ke tempat lain.

Dengan demikian, diharapkan para pegawai dapat bekerja sama secara sinergi baik secara vertical maupun horizontal untuk menjalankan tugas serta bertanggung jawab atas beban kerja yang diberikan organisasi. Semua itu dapat terlaksana apabila perusahaan mampu mengoptimalkan semua anggota organisasi untuk melaksanakan tugastugasnya secara efektif dan efisien.

Guna mencapai kualitas sumber daya manusia yang memenuhi persyaratan sesuai dengan perkembangan dan standar modern, maka sejumlah program seyogyanya dilakukan oleh Badan Kepegawaian Daerah Kabupaten Lampung Tengah. Salah satu program peningkatan yaitu dengan memberikan pendidikan dan pelatihan yang inovatif baik secara internal maupun secara eksternal. Adapun program pelatihan dan pendidikan dimaksud adalah dibidang kepegawaian. Sedangkan untuk meningkatkan kinerja pegawai, Badan Kepegawaian Daerah Kabupaten Lampung Tengah melakukannya melalui program mutasi Pegawai, sebagai upaya adanya perubahan dalam struktur organisasi dan untuk lebih meningkatkan kinerja pegawai.

Pelaksanaan mutasi Pegawai yang diterapkan oleh Pemerintah Daerah Kabupaten Lampung Tengah dapat diartikan sebagai perpindahan jabatan pegawai sebagai bentuk pengembangan, pembinaan, dan pengayaan pengalaman pegawai. Hal demikian sebenarnya hanya diberikan kepada pegawai tertentu 
yang memiliki prestasi kerja yang dinilainya cukup baik. Kondisi di Badan Kepegawaian Daerah Kabupaten Lampung Tengah sendiri jika diamati dari sudut pelaksanaan program mutasi, sepertinya tidak ada bedanya dengan program promosi. Karena dengan adanya promosi, dengan sendirinya pasti terjadi juga demosi/mutasi Pegawai. Keduanya juga dilatarbelakangi oleh faktor prestasi kerja pegawai.

Dalam pelaksanaan mutasi harus benar-benar berdasarkan penilaian yang objektif dan didasarkan atas indeks prestasi yang dicapai oleh pegawai mengingat sistem pemberian mutasi dimaksudkan untuk memberikan peluang bagi para pegawai negeri sipil untuk mengembangkan potensi yang dimilikinya.

$$
\text { Melalui mutasi Pegawai }
$$

Pemerintah Daerah Kabupaten Lampung Tengah dapat mengambil langkahlangkah yang akan membantu memenuhi keinginan dan kebutuhan pegawai sesuai dengan kemampuan pegawainya. Dengan kondisi tersebut, diharapkan pegawai memiliki prilaku dan prestasi kerja yang baik dalam melaksanakan pekerjaannya sebagai penunjang upaya pencapaian tujuan, langkah tersebut diantaranya dengan penerapan mutasi Pegawai.

Mutasi Pegawai selain dapat meningkatkan prestasi kerja, dapat pula memberikan kesempatan kepada Pegawai untuk lebih meningkatkan prestasi kerja Pegawai. Dalam membuat keputusan tentang pemberian kebijakan mutasi Pegawai berbagai pertimbangan, karena keputusan yang salah dalam melaksanakan mutasi akan menimbulkan efek samping yang tidak baik bagi Pegawai dan Pemerintah Daerah Kabupaten Lampung Tengah itu sendiri khususnya Badan Kepegawaian Daerah Kabupaten Lampung Tengah.

Pegawai yang mutasi harus dinilai terlebih dahulu untuk mengetahui kompetensi yang dimiliki sebagai bahan pertimbangan bagi pembuat keputusan untuk pengembangan dan penempatan pegawai tersebut ke bidang yang tepat sesuai dengan kebutuhan dan persyaratan Pegawai pada Pemerintah Daerah Kabupaten Lampung Tengah yang disebut dengan "asesmen". Sehingga akan meningkatkan motivasi, kinerja dan prestasi kerja sesuai dengan kompetensi dan pengalamannya serta tidak salah dalam pengambilan keputusan dengan pelaksanaan mutasi Pegawai tersebut. Moekijat (2017 : 130) 
mengatakan bahwa prestasi kerja adalah kemampuan sekelompok orang untuk bekerjasama dengan giat dan konsekwen dalam tujuan bersama. Jadi, prestasi kerja adalah melakukan pekerjaan secara lebih giat sehingga dengan demikian pekerjaan akan dapat diharapkan lebih cepat dan lebih baik lagi.

Oleh karena itu, prestasi kerja terhadap sumber daya manusia harus dikembangkan kemampuannya agar dapat menyesuaikan dengan perkembangan pengetahuan teknologi yang sangat pesat dan perkembangan sosial yang begitu cepat, sehingga pegawai terpacu untuk bekerja lebih giat dan bersemangat demi tercapainya tujuan yang diharapkan Pemerintah Daerah Kabupaten Lampung Tengah dan untuk kesejahteraan pegawai. Menurut Nitisemito, (2016:47) mengatakan bahwa tujuan dan manfaat prestasi kerja adalah untuk meningkatkan produktivitas yang lebih baik. Sehingga instansi atau organisasi perlu menimbulkan prestasi kerja pegawai yang tinggi, akan mempermudah untuk mencapai tujuan organisasi yang telah ditetapkan sebelumnya, sementara apabila prestasi kerja rendah maka produktivitas juga rendah.
Di samping itu faktor pendorong yang mengakibatkan pegawai berprestasi dalam bekerja adalah mutasi Pegawai yang berasal dari internal yaitu Pemerintah Daerah Kabupaten Lampung Tengah langsung kepada pegawai dan internal individu pegawai sendiri yang menimbulkan semangat untuk bekerja keras agar tujuan yang telah direncanakan Pemerintah Daerah Kabupaten Lampung Tengah tercapai guna menghasilkan kinerja yang efektif dan efisien. Penampilan kinerja pegawai tidak terbatas kepada pegawai yang memangku jabatan fungsional maupun struktural. Akan tetapi juga kepada keseluruhan jajaran pegawai di dalam Pemerintah Daerah Kabupaten Lampung Tengah. Sesungguhnya pegawai yang baik adalah pegawai yang mengutamakan tugas demi tercapainya tujuan BaPemerintah Daerah Kabupaten Lampung Tengah. Permasalahan diatas diduga akan muncul sebagai cerminan dari sistem dan aspek pengelolaan pegawai.

Prestasi kerja pegawai juga dapat menurun apabila pihak atasan tidak memperhatikan kepentingan para bawahan. Hal ini akan menurunkan prestasi kerja para pegawai. Indikator dari turunnya prestasi kerja antara lain 
rendahnya produktivitas, tingkat absensi pegawai tinggi, gaji rendah, dan lainlain. Dengan demikian pastilah akan mempengaruhi prestasi kerja pegawai pada Pemerintah Daerah Kabupaten Lampung Tengah.

Kondisi seperti ini diharapkan dapat diantisipasi guna keberhasilan tugas dan dukungan oleh bawahannya. Artinya, bawahan membutuhkan pembinaan untuk bekal tugas. Dengan adanya mutasi Pegawai, maka diharapkan dapat memotivasi dirinya atau penilaian dari pimpinan kepada pegawai guna meningkatkan kinerja agar mencapai tingkat keberhasilan yang diinginkan Pemerintah Daerah Kabupaten Lampung Tengah. Disamping itu bawahan menghendaki agar pemimpin mereka memiliki kemampuan, keterampilan, teknis kerja yang unggul dan kemauan bekerja sama dengan bawahan. Perhatian utama dalam penelitian ini adalah mengenai "pengaruh mutasi Pegawai terhadap prestasi kerja pada Pemerintah Daerah Kabupaten Lampung Tengah", karena dengan adanya mutasi Pegawai, diharapkan seorang pegawai pada Pemerintah Kabupaten Lampung Tengah dapat meningkatkan prestasi kerja dengan lebih baik.
Hal inilah yang mendorong peneliti untuk meneliti masalah mutasi yang dikaitkan dengan prestasi kerja pegawai dengan pemikiran bagaimana upaya untuk menumbuhkan prestasi kerja dikalangan pegawai sehingga prestasi kerja pegawai dapat meningkat, khususnya pegawai pada Pemerintah Daerah Kabupaten Lampung Tengah.

Adapun yang menjadi tujuan penelitian ini adalah untuk mendeskripsikan pelaksanaan mutasi pegawai pada Pemerintah Daerah Kabupaten Lampung Tengah, menganalisis prestasi kerja pegawai pada Pemerintah Daerah Kabupaten Lampung Tengah, menganalisis pengaruh mutasi pegawai terhadap prestasi pegawai pada Pemerintah Daerah Kabupaten Lampung Tengah.

\section{METODE PENELITIAN}

$$
\text { Dalam penelitian ini }
$$
menggunakan penelitian kuantitatif. Ada beberapa pendekatan yang dapat dipakai dalam melakukan analisis terhadap data yang diperoleh dari lapangan yaitu analisis kuantitatif. Dalam penelitian ini perhitungannya menggunakan bantuan program SPSS Versi 16.0 for windows untuk memudahkan pengerjaan. Teknik 
pengumpulan data yang digunakan quisioner dan dokumentasi serta penelitian perpustakaan. Dikarenakan dalam penelitian terdapat hipotesis, maka untuk menguji hipotesis dengan uji-t atau Probabiltas volue ( $\rho$-volue).

\section{HASIL DAN PEMBAHASAN}

Populasi adalah wilayah generalisasi yang terdiri dari obyek/subyek yang mempunyai kualitas dan karakteristik tertentu yang ditetapkan oleh peneliti untuk dipelajari dan kemudian ditarik kesimpulannya, (Sugiyono, 2012:43). Berdasarkan dari arti populasi tersebut, maka dalam penelitian ini respondennya adalah pegawai yang terkena mutasi di Lingkungan Pemerintahan Daerah Kabupaten Lampung Tengah sebanyak 60 (enam puluh) pegawai.

Tabel 1. Berdasarkan Golongan

\begin{tabular}{|c|l|c|c|}
\hline No & \multicolumn{1}{|c|}{ Uraian } & Jumlah Pegawai & $\%$ \\
\hline a. & Golongan IV & 4 orang & 07 \\
b. & Golongan III & 33 orang & 55 \\
c. & Golongan II & 23 orang & 38 \\
d. & Golongan I & - & \\
\hline & Jumlah & 60 orang & 100 \\
\hline
\end{tabular}

Sumber : Data diperoleh dari Kantor BKD

Lampung Tengah, Tahun 2019

Tabel 2. Berdasarkan Pendidikan

\begin{tabular}{|c|l|c|c|}
\hline No & \multicolumn{1}{|c|}{ Uraian } & $\begin{array}{c}\text { Jumlah } \\
\text { Pegawai }\end{array}$ & $\%$ \\
\hline a. & S2 & 4 orang & 07 \\
b. & S1 & 33 orang & 55 \\
c. & D3 & 11 orang & 18 \\
d. & SLTA / sederajat & 12 orang & 20 \\
\hline & Jumlah & 60 orang & 100 \\
\hline
\end{tabular}

Sumber : Data diperoleh dari Kantor BKD

Lampung Tengah, Tahun 2019
Tabel 3. Berdasarkan Jenis Kelamin

\begin{tabular}{|c|l|c|c|}
\hline No & \multicolumn{1}{|c|}{ Uraian } & $\begin{array}{c}\text { Jumlah } \\
\text { Pegawai }\end{array}$ & $\%$ \\
\hline a. & Laki-laki & 38 orang & 63,0 \\
b. & Perempuan & 22 orang & 37,0 \\
\hline & Jumlah & 60 orang & 100 \\
\hline
\end{tabular}

Sumber : Data diperoleh dari Kantor BKD

Lampung Tengah, Tahun 2019

\section{Hasil Penelitian}

Kesempatan menduduki jabatan merupakan persoalan tersendiri yang dihadapi oleh seorang pegawai. Sebagian pegawai mendapatkan kesempatan yang baik dalam mendapatkan jabatan, namun sebagian pegawai lainnya kurang mendapatkan kesempatan. Pegawai negeri dalam menduduki jabatan tergantung dari kepangkatan dan juga masalah prestasi kerja mereka. Namun sesungguhnya selain itu posisi jabatan juga memberikan peluang kepada pegawai negeri untuk lebih mengenal pejabat. Pejabat dalam pegawai negeri memegang kendali keputusan, oleh karenanya apabila pegawai negeri dekat dengan pejabat, maka mereka akan berkesempatan untuk menduduki jabatan dan bahkan memperoleh apa yang diinginkannya.

Kebijakan untuk pelaksanaan mutasi merupakan sesuatu yang sangat normatif. Dalam urusan mutasi, kebijakan Kepala Pemerintah Daerah 
Kabupaten Lampung Tengah dalam melakukan mutasi disadari sebagai sesuatu yang mutlak dilakukan. Jika mutasi tidak dilakukan maka ada sesuatu yang tidak beres dalam mengelola pekerjaan dalam organisasi.

Seorang pegawai pada Badan Kepegawaian Daerah Kabupaten Lampung Tengah karena hal-hal tertentu memaksanya untuk mulai dari satu unit tertentu ke unit lain dalam wilayah dan Pemerintah Daerah Kabupaten Lampung Tengah. Banyak hal yang menyebabkan mutasi Pegawai antar unit dilakukan, diantaranya adalah :

a. Ingin mengembangkan karier di tempat yang baru karena adanya promosi

b. Keahliannya sangat dibutuhkan di unit tertentu sehingga diminta mutasi kesana

c. Hal lain yang bersifat pribadi.

Alur Mutasi Intern Pegawai Negeri Sipil:

1. Pegawai Negeri Sipil yang bersangkutan mengajukan berkas Permohonan Alih Tugas kepada Bupati Lampung Tengah Melalui Badan kepegawaian Daerah Lampung Tengah

2. Setelah dirasa cukup semua berkas yang ada akan dimasukkan kedalam Minut Surat Keputusan
Bupati tentang Penempatan

Pegawai Negeri Sipil Kabupaten Lampung Tengah maka akan di laporkan kepada Kepala Badan Kepegawaian Daerah Lampung Tengah

3. Setelah Kepala Badan Daerah Kabupaten Lampung Tengah telah menyetujui Minut Surat Keputusan tersebut maka akan diserahkan kepada Asisten Bidang Administrasi Umum

4. Setelah Minut Surat Keputusan Bupati tentang Penempatan Pegawai Negeri Sipil Kabupaten Lampung Tengah telah disetujui oleh Asisten Bidang Administrasi Umum maka berkas tersebut diserahkan kepada Bupati Lampung Tengah

5. Setelah disetujui oleh Bupati Lampung Tengah maka berkas tersebut akan di buatkan Surat Keputusan Bupati tentang Penempatan Pegawai Negeri Sipil

6. Setelah selesai maka akan di berikan kepada Pegawai Negeri Sipil yang bersangkutan

7. Pegawai Negeri Sipil tersebut maka sudah dapat bekerja pada Dinas/Badan yang dituju. 
Syarat Mutasi Intern Pegawai pada Pemerintah Kabupaten Lampung Tengah:

1. Asli sah Surat Permohonan Alih Tugas Yang Bersangkutan ditujukan kepada Bapak Bupati Lampung Tengah memuat tentang data diri sebagai Pegawai Negeri sipil dan alasan untuk alih tugas.

2. Asli Sah Surat Rekomendasi dari Dinas/Badan yang dituju

3. Asli Sah Surat Persetujuan Alih Tugas Dinas/Badan yang akan di tinggalkan

4. Salinan Sah Surat Keputusan Bupati tentang Pengangkatan Calon Pegawai Negeri Sipil (SK $80 \%)$

5. Salinan Sah Surat Keputusan Bupati tentang Pengangkatan Pegawai Negeri Sipil (SK 100\%)

6. Salinan Sah Surat Keputusan Bupati tentang Kenaikan Pangkat Pegawai Negeri Sipil terakhir

7. Salinan Sah Sasaran Kerja Pegawai (SKP) 1 tahun terakhir Dalam penelitian ini peneliti akan memberi gambaran mengenai prestasi apa saja yang telah diperoleh Badan Kepegawaian Daerah Kabupaten Lampung Tengah yaitu : a. Adanya umpan balik pelaksanaan kerja antara pegawai bawahan dan atasan yang dimana mereka dapat membetulkan kegiatan kegiatan mereka

b. Adanya penyesuaian penyesuaian kompensasi yang dimana pegawai dapat membantu para pengambil keputusan dalam menentukan kebijakan yang dibuat

c. Adanya penempatan pegawai yang sesuai dengan prestasi kerjanya dimana merupakan bentuk penghargaan

d. Adanya latihan dan pengambangan untuk pegawai pekerjaan menjadi lebih baik dan potensi terus dapat dikembangkan.

e. Pegawai dapat merencanakan dan mengembangkan karier dengan baik

f. Mengurangi kesalahan kesalahan dalam desain pekerjaan

g. Pegawai dapat menghadapi tantangan tantangan eksternal

Serta frekuensi mutasi yang terjadi pada Pemerintah Daerah Kabupaten Lampung Tengah, setiap 1 tahun sekali dilakukan mutasi Pegawai berdasarkan kemauan sendiri atau berdasarkan penilaian kerja pimpinan sebanyak 2 (dua) sampai 4 (empat) pegawai yang menginginkan pindah unit 
atau pimpinan menginginkan ke sutau unit tertentu.

Tabel 4

Hasil Uji Validitas Kuisioner Mutasi Pegawai

\begin{tabular}{|c|c|c|c|}
\hline $\begin{array}{c}\text { No } \\
\text { Item }\end{array}$ & Rxy & $\begin{array}{c}\text { R table } \\
(0,05: 60)\end{array}$ & Keterangan \\
\hline 1 & 0,890 & 0.254 & Valid \\
\hline 2 & 0,807 & 0.254 & Valid \\
\hline 3 & 0,890 & 0.254 & Valid \\
\hline 4 & 0,689 & 0.254 & Valid \\
\hline 5 & 0,890 & 0.254 & Valid \\
\hline 6 & 0,807 & 0.254 & Valid \\
\hline 7 & 0,689 & 0.254 & Valid \\
\hline 8 & 0,868 & 0.254 & Valid \\
\hline
\end{tabular}

Sumber : Pengolahan Data SPSS Versi 16,0 Tahun 2019

Hasil perhitungan uji validitas terhadap kuesioner mutasi Pegawai menunjukkan bahwa seluruh item kuesioner semuanya valid. Item kuesioner dinyatakan valid karena Rxy untuk item tersebut lebih besar dari $r$ tabel pada taraf signifikansi $=5 \%$ yaitu sebesar 0,254 maka dapat disimpulkan dari hasil uji validitas dapat dinyatakan bahwa seluruh pertanyaan dalam kuesioner mutasi Pegawai dapat dipercaya untuk mengambil data penelitian.

Tabel 5

Hasil Uji Validitas Kuisioner Prestasi Kerja

\begin{tabular}{|c|c|c|c|}
\hline No Item & Rxy & $\begin{array}{c}\text { R table } \\
(0,05: 60)\end{array}$ & Keterangan \\
\hline 1 & 0,852 & 0.254 & Valid \\
\hline 2 & 0,901 & 0.254 & Valid \\
\hline 3 & 0,852 & 0.254 & Valid \\
\hline 4 & 0,901 & 0.254 & Valid \\
\hline 5 & 0,901 & 0.254 & Valid \\
\hline 6 & 0,588 & 0.254 & Valid \\
\hline 7 & 0,901 & 0.254 & Valid \\
\hline 8 & 0,852 & 0.254 & Valid \\
\hline
\end{tabular}

Sumber : Pengolahan Data SPSS Versi 16,0 Tahun 2019
Hasil perhitungan uji validitas terhadap kuesioner Prestasi kerja menunjukkan bahwa seluruh item kuesioner semuanya valid. Item kuesioner dinyatakan valid karena Rxy untuk semua item kuesioner lebih besar dari $r$ tabel pada taraf signifikansi $=5 \%$ yaitu sebesar 0,254. Maka dapat disimpulkan dari hasil uji validitas dapat dinyatakan bahwa seluruh pertanyaan dalam kuesioner prestasi kerja dapat dipercaya untuk mengambil data penelitian.

Tabel 6

Hasil Uji Reliabilitas Kuesioner

\begin{tabular}{|l|c|c|l|}
\hline \multicolumn{1}{|c|}{ Variabel } & $\mathrm{R}$ tt & $\begin{array}{c}\text { R Tabel } \\
(0,05: 60)\end{array}$ & Keterangan \\
\hline $\begin{array}{l}\text { Mutasi } \\
\text { Pegawai }\end{array}$ & 0,791 & 0.254 & Reliabel \\
\hline $\begin{array}{l}\text { Prestasi } \\
\text { Kerja }\end{array}$ & 0,795 & 0.254 & Reliabel \\
\hline
\end{tabular}

Sumber : Pengolahan Data SPSS Versi 16,0 Tahun 2019

Hasil uji reliabilitas terhadap kuesioner mutasi Pegawai dan prestasi kerja diperoleh koefisien reliabilitas $\left({ }^{\mathrm{r}} \mathrm{tt}\right)$ masing-masing sebesar 0,791 dan 0,795. Nilai tersebut lebih besar dari pada taraf signifikansi $=5 \%$ yaitu sebesar 0,254 sehingga seluruh kesioner dinyatakan reliable (andal). Sehingga dapat disimpulkan bahwa data yang dikumpulkan melalui kuesioner mutasi Pegawai dan prestasi kerja dinyatakan reliabel dan dapat dipercaya. 
Dari hasil persamaan yang diperoleh, dapat dijelaskan pola pengaruh mutasi Pegawai (X) terhadap variabel terikat prestasi kerja $(\mathrm{Y})$ diatas adalah sebagai berikut:

1. Terdapat pola pengaruh positif variabel bebas mutasi Pegawai (X)terhadap variabel terikat prestasi kerja.

2. Apabila skor variabel bebas muatsi Pegawai (X) besarnya sama dengan 0, maka skor prestasi kerja (Y) adalah sebesar konstanta (a), yaitu 0,500 satuan.

Bahwa variabel bebas mutasi Pegawai (X) berpengaruh terhadap variabel terikat prestasi kerja (Y) pada Badan Kepegawaian Daerah Kabupaten Lampung Tengah. Berdasarkan penjelasan diatas, secara umum dapat dinyatakan bahwa mutasi Pegawai (X) memiliki pola pengaruh positif dan signifikan terhadap prestasi kerja (Y). Ini menunjukkan bahwa apabila mutasi Pegawai (X) ditingkatkan, maka prestasi kerja (Y) akan meningkat.. Sebaliknya, apabila mutasi Pegawai (X) berkurang maka akan terjadi penurunan prestasi kerja.

Berdasarkan hasil nilai total seluruh butir pertanyaan untuk suatu variabel dengan menggunakan rumus
Korelasi Product Moment. Pengaruh Mutasi Pegawai Terhadap Prestasi Kerja Pada Badan Kepegawaian Daerah Kabupaten Lampung Tengah sebesar 0,986 atau $98,6 \%$.

Diketahui hasil analisis determinasi dapat dilihat pada output Model Summary dari hasil analisis regresi linier sederhana. Berdasarkan output diperoleh angka R-square sebesar 0,973 atau 97,3\%. Hal ini menunjukan bahwa persentase pengaruh variabel bebas $(\mathrm{X})$ terhadap variabel terikat $(\mathrm{Y})$ sebesar 97,3 \%. Sedangkan sisanya sebesar 2,7 \% dipengaruhi atau dijelaskan oleh variabel lain yang tidak dimasukkan dalam metode penelitian ini.

\section{Pembahasan}

Dari hasil analisis regresi diketahui bahwa Pelaksanaan Mutasi Pegawai pada Pemerintah Daerah Kabupaten Lampung Tengah, terdapat pola pengaruh positif dan signifikan antara mutasi Pegawai (X) terhadap prestasi kerja (Y) pada Pemerintah Daerah Kabupaten Lampung Tengah.

Bahwa apabila mutasi Pegawai ditingkatkan sebesar satu satuan maka akan diikuti dengan meningkatnya prestasi kerja. Sebaliknya, jika mutasi 
Pegawai menurun sebesar satu satuan maka akan diikuti dengan menurunnya prestasi kerja

Keterkaitan pengaruh antara mutasi Pegawai dengan prestasi kerja Pemerintah Daerah Kabupaten Lampung Tengah adalah 0,986 atau 98,6 \% Dengan demikian menunjukan bahwa ada pengaruh yang erat antara mutasi Pegawai dengan prestasi kerja. Oleh karena nilai t hitung > t tabel (45.782> 2,00172) dan signifikansi $(0,000<0,05)$ maka Ho ditolak, artinya bahwa ada pengaruh secara signifikan antara variabel bebas mutasi Pegawai (X) dengan variabel terikat prestasi kerja (Y). Karena t hitung nilainya positif, berarti variabel bebas mutasi Pegawai (X) berpengaruh positif dan signifikan terhadap variabel terikat (Y).

Besarnya pengaruh variabel bebas mutasi Pegawai (X) terhadap variabel terikat prestasi kerja (Y) sebesar 0,973 atau 97,3 \%. Sedangkan sisanya 2,7\% dipengaruhi atau dijelaskan oleh variabel lain yang tidak dimasukkan ke dalam metode penelian ini.

\section{SIMPULAN DAN SARAN}

\section{Simpulan}

1. Bahwa pelaksanaan mutasi Pegawai terhadap prestasi kerja pada Pemerintah Daerah Kabupaten
Lampung Tengah, dari hasil analisis regresi diketahui bahwa Pelaksanaan Mutasi Pegawai pada Badan Kepegawaian Daerah Kabupaten Lampung Tengah, terdapat pola pengaruh positif dan signifikan antara mutasi Pegawai (X) terhadap prestasi kerja (Y).

2. Bahwa Prestasi kerja pegawai pada Pemerintah Daerah Kabupaten Lampung Tengah, apabila mutasi pegawai ditingkatkan sebesar satu satuan maka akan diikuti dengan meningkatnya prestasi kerja. Sebaliknya, jika mutasi Pegawai menurun sebesar satu satuan maka akan diikuti dengan menurunnya prestasi kerja

3. Bahwa pengaruh mutasi Pegawai terhadap prestasi kerja pada Pemerintah Daerah Kabupaten Lampung Tengah, adalah dengan menggunakan analisis regresi sederhana dapat diketahui bahwa besarnya persentase pengaruh mutasi Pegawai terhadap prestasi kerja pada Pemerintah Daerah Kabupaten Lampung Tengah adalah berdasarkan jawaban responden sebesar 97,3\%. Sedangkan sisanya sebesar $2,7 \%$ dipengaruhi atau dijelaskan oleh 
variabel lain yang tidak dimasukkan dalam metode penelitian ini. penempatan mutasi sesuai dengan yang diharapkan.

\section{DAFTAR PUSTAKA}

1. Hendaknya Pemerintah Daerah Kabupaten Lampung Tengah meneruskan program mutasi Pegawai secara berkala tersebut. Dimana program mutasi Pegawai ini dilakukan sesuai dengan Peraturan Pemerintah yang berlaku atau sesuai dengan Surat Keputusan Bupati yang disesuaikan berdasarkan UndangUndang Kepegawaian Negara Republik Indonesia. Sehingga tercapainya tujuan Pemerintah Daerah Kabupaten Kabupaten Lampung Tengah yang optimal.

2. Hendaknya pegawai Pemerintah Daerah Kabupaten Lampung Tengah yang merupakan Instansi Pemerintah, agar selalu meningkatkan prestasi kerjanya, sehingga tercapainya tujuan Pemerintah Daerah Kabupaten Kabupaten Lampung Tengah secara efektif dan efisien.

3. Hendaknya pegawai Pemerintah Daerah Kabupaten Lampung Tengah dapat mempertahankan pengaruh yang signifikan dan positif dalam meningkatkan prestasi kerja, agar
Danim, S. 2016. Trategic Planning PT Gramedia Indonesia, Jakarta

Hasibuan, M.S.P. 2014. Sumber Daya Manusia dan Produktifitas Kerja. CV Mandar Maju, Jakarta

Indrianto. 2012. Identifikasi Masalah Dalam Penelitian PT Gramedia Indonesia, Jakarta

Mangkunegara, A,P. 2011. Prestasi Kerja dan Penilaian Kinerja. PT Rhineka Cipta Persada, Jakarta

Moekijat. 2017. Tata Kerja dan Prestasi Kerja. Citra Aditya Bhakti, Jakarta

Nitisemito, A. S. 2016. Membangun Sumber Daya Manusia dan Aplikasinya. PT Bumi Aksara, Jakarta

Wahyudi, B. 2017. Landasan Mutasi Karyawan Prenada Media Jakarta

Sastrohadiwiryo. 2016. Manajemen Tenaga Kerja Indonesia. PT Raja Grafindo Persada. Jakarta

Simamora. 2016. Manajemen Sumber Daya Manusia PT Raja Grafindo Persada Jakarta

Siswanto. 2012. Manajemen Sumber Daya Manusia.Tarsito, Bandung 